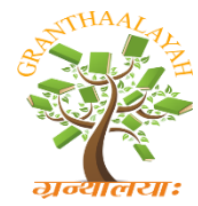

INTERNATIONAL JOURNAL OF RESEARCH GRANTHAALAYAH

A knowledge Repository

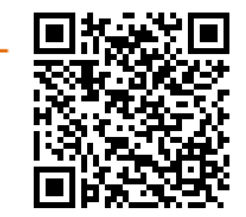

Management

\title{
PRADHAN MANTRI JAN DHAN YOJANA (PMJDY) - A CONCEPTUAL STUDY
}

\author{
Neha Sharma $^{* 1}$, Dr. Ruchi Goyal ${ }^{2}$ \\ ${ }^{* 1}$ Research Scholar, JECRC University, Jaipur, Rajasthan, India \\ ${ }^{2}$ Associate Professor, JECRC University, Jaipur, Rajasthan, India
}

DOI: https://doi.org/10.29121/granthaalayah.v5.i4.2017.1806

\begin{abstract}
A successful development is marked with the establishment of a stable and useful financial system for the entire population. Indian government implemented many initiatives since independence for financial inclusion and recently launched Pradhan Mantri Jan-Dhan Yojana (PMJDY) to overcome the loopholes of previous initiatives. PMJDY is major financial plan with the objective of covering all households in the country with banking facilities along with inbuilt insurance coverage. With this background, the study has been conducted and tries to find out the success rate of inclusion process in rural areas of Jaipur district. For the purpose of the study, both primary data and secondary data have been collected. Correlation (r) test is used to find out the relationship between the socio economic backgrounds and the financial inclusion process. Findings show that Income, financial information from various channels and awareness of PMJDY are influential factors leading to inclusion. Nearness to banks increases the likelihood of inclusion.
\end{abstract}

Keywords: Financial Inclusion; PMJDY; Financial Institutions; Banks; Bank Account.

Cite This Article: Neha Sharma, and Dr. Ruchi Goyal. (2017). "PRADHAN MANTRI JAN DHAN YOJANA (PMJDY) - A CONCEPTUAL STUDY." International Journal of Research Granthaalayah, 5(4), 143-152. https://doi.org/10.29121/granthaalayah.v5.i4.2017.1806.

\section{Introduction}

Among economists, the general consensus is that financial development acts as a promoter in the overall economic growth and development. Moreover, empirical research demonstrates that development of a strong, sound financial system contributes to economic growth. As a result, most developing countries are promoting financial inclusion as a policy goal, especially for those who are ignored by formal sector institutions.

In India, financial inclusion has always been a priority, since 1969, when banks were nationalized, the strategy for addressing the banking needs of the poor has been biased toward 
providing credit, neglecting other aspects, such as building a deposit base, promoting a savings culture, or extending the payment network.

However, over the last decade, India's financial inclusion agenda has seen a strategic shift from an emphasis on credit to a more comprehensive approach toward financial services, particularly opening bank accounts and offering basic financial products such as insurance. This shift has been partly driven by the need to achieve other public policy goals, such as replacing product subsidies with cash transfers, which requires beneficiaries to have bank accounts for advancing the transfers.

The recently launched Pradhan Mantri Jan-Dhan Yojana (PMJDY) appears to address most of the concerns related to a more concrete and substantial engagement with the poor as part of a financial inclusion strategy to be undertaken in a mission mode. The objective of PMJDY is to ensure 'access to various financial services like availability of basic savings bank account, access to need based credit, remittances facility, insurance and pension to the excluded sections, i.e., weaker sections and low income groups'. In this paper we will discuss about the theoretical soundness of PMJDY and evaluate it critically.

\section{Review of Literature}

\subsection{Theoretical Analysis of Pradhan Mantri Jan Dhan Yojana}

Initiatives for financial inclusion are being announced at regular intervals by Governments, Central Banks of countries and developmental organizations like the United Nations. For example, the German Bankers' Association introduced current banking account for 'everyman'. In the United States, the Community Reinvestment Act (1997) requires banks to offer credit throughout their entire area of operation. In South Africa, a low cost bank account called 'Mzansi' or 'no-frill' bank account was launched for financially excluded people in 2004 (Gupte R. et al. (2012).

In Brazil, branchless Banking i.e. banking correspondents (BCs) strategy is used which spread access to banking through agents. Kenya used - Bank without a Bank i.e. mobile banking as financial inclusion strategy and demonstrated the best use of Technology for improving the inclusion (Barua, et al. (2016)). PMJDY covers these strategies to outreach the weaker section of the society.

Aiyar (2014) asserts that financial inclusion requires sustained efforts for several years, with an emphasis more on quality rather than speed. By shifting the focus to cash transfers, the massive dormant accounts could also be activated over time. Accordingly, the design of the scheme needs a shift of focus in order to deliver on the objectives.

Singh and Naik (2014) assert that the most important factor for the success of financial inclusion would be changing the mindset of the financial institutions. Chopra (2014) defined that the new financial inclusion programme has the right intentions and addresses several design issues. In his view consumers will need to be well educated about the power of bank accounts and their rights 
to overdraft facilities, insurance, etc., otherwise intermediaries will take advantage of the money intended for them.

Tewari (2014) points out three basic concerns regarding the Rupay debit cards - a critical component of the scheme. According to Finance Ministry sources, a greater dependence on online biometric-based transactions through the $\mathrm{BC}$ model would be preferable.

Rajan (2014) stated that as far as financial inclusion targets were concerned, universality, not just speed or numbers, was essential. It would be a waste if duplicate accounts were opened, if full coverage was not achieved and if accounts were not used. RBI would work with banks to ensure the effectiveness of the measures taken. This would suggest that there is substance both to charges of differences in the government and RBI perceptions of the pace and content of the financial inclusion drive; as well as the views of skeptics unconvinced about the feasibility and success of the campaign mode adopted.

\section{Pradhan Mantri Jan Dhan Yojana in India}

"Pradhan Mantri Jan-Dhan Yojana (PMJDY)" was announced on 15 August, 2014 and launched on 28 August, 2014 as a National Mission for Financial Inclusion. This Mission has an ambitious objective of covering all households in the country with banking facilities and having a bank account for each household. PMJDY works with the philosophy of "Sab Ka Sath Sab Ka Vikas". Comprehensive financial inclusion (FI) under the mission is based on six pillars. These are proposed to be achieved in two phases as under:

- Phase I (15 August 2014-14 August 2015)

$>$ Universal access to banking facilities.

$>$ Providing Basic Banking Accounts with overdraft facility and RuPay Debit card to all households.

$>$ Financial Literacy Programme.

- $\quad$ Phase II (15 August 2015-15 August 2018)

$>$ Creation of Credit Guarantee Fund.

$>$ Micro-Insurance.

$>$ Unorganized sector Pension schemes like Swavalamban.

\subsection{Strategies to Achieve the Above Objectives}

A broad collaborative strategy is proposed with all stake holders. Public-Private partnerships are encouraged. Inter-department convergence and synergies will be utilized and existing rural infrastructure of post offices having Gramin Dak Sewaks would be optimally utilized to become Bank Mitr (Business correspondent) of the Banks. Bank Mitr model is used for expansion of banking services. Technological innovations like RuPay card and mobile banking would be made use of. Banks will use the RBI's scheme for subsidy on rural ATMs.

In order to cover each household with bank accounts convergence with the National Rural Livelihood Mission (NRLM) in rural areas and National Urban Livelihood Mission (NULM) in urban areas has been done. The expansion plans of the Department of Telecom to provide telecom connectivity in difficult areas would be effectively utilized for the provision of banking 
facilities in these areas. Department of Telecom has been requested to ensure that problems of poor and no connectivity are resolved on priority.

\section{Summary: Annual Progress Report}

The numbers in Table 1 are an indication of the difficult path and a distant goal to be covered to make inclusion under PMJDY more meaningful. As the table indicates, while there is significant progress in the reduction of zero balance accounts, it is still a sizeable number. Given that the overdraft account has been linking the account to the Aadhaar number and less than $50 \%$ of the new accounts have been linked to Aadhaar, this is a long path to be taken. The overdraft facility has been extended only to about $0.15 \%$ of the potentially eligible (Aadhaar-linked) accounts.

\begin{tabular}{|lc|}
\hline \multicolumn{2}{|c|}{ Table 1: Summary statistics on the PMJDY as of 1 August 2015 } \\
\hline Total number of PMJDY accounts opened & 175.6 million accounts \\
Total number of PMJDY accounts with zero balance & 80 million accounts \\
Number of accounts where RuPay card was issued & 155.6 million accounts \\
Number of accounts with Aadhaar seeding & 72.7 million accounts \\
Number of accounts provided with overdraft facility & 0.10 million accounts \\
Beneficiaries under Pradhan Mantri Suraksha Beema & 66.2 million customers \\
Yojana (accident insurance) & \\
Beneficiaries under Pradhan Mantri Jeevan Jyoti Beema & 22.2 million customers \\
Yojana (life insurance) & \\
Beneficiaries under the Atal Pension Yojana (pension) & 588,000 customers \\
\hline
\end{tabular}

Source: M.S. Sriram (2015)

from the statistics above, it can be seen that the accident and life insurance coverage has been availed by a much smaller number and the pension scheme has not picked up steam. other elements of the six pillars where the customer has to consciously pay (even if a marginal amount) is evident.

Table 2 clearly show an increase both in the number of accounts opened and also the account balances under the PMJDY scheme. Highest number of bank accounts was opened by the public sector banks. In 2014, 35.37 million accounts were opened which increased to 226.14 million in year 2017. Regional rural bank and private sector bank also shows a continuous increase in accessing people especially in rural areas. Data of table 1 are shown graphically in figure 1. Table 2 Progress report of PMJDY bank accounts from 2014 to 2017. 
Table 2:

\begin{tabular}{|l|l|l|l|l|l|l|l|l|l|l|l|l|l|l|}
\hline & \multicolumn{9}{|c|}{$(18.09 .2014)$} & \multicolumn{3}{|c|}{$(31.08 .2015)$} & \multicolumn{3}{|c|}{ (29.06.16) } & \multicolumn{3}{|c|}{ (29.3.2017) } \\
\hline Bank & Rural & $\begin{array}{l}\text { Urba } \\
\mathrm{n}\end{array}$ & total & Rural & Urban & Total & Rural & Urban & Total & Rural & Urban & Total \\
\hline $\begin{array}{l}\text { Public } \\
\text { sector } \\
\text { banks }\end{array}$ & 9 & 19.0 & 16.28 & 35.3 & 75.30 & 61.90 & 137.20 & 97.82 & 77.15 & 174.98 & 123.37 & 102.77 & 226.14 \\
\hline $\begin{array}{l}\text { Rural } \\
\text { Regiona } \\
\text { l Bank }\end{array}$ & 6.01 & 0.87 & 6.88 & 26.80 & 4.60 & 31.40 & 34.00 & 5.59 & 39.59 & 39.79 & 6.58 & 64.37 \\
\hline $\begin{array}{l}\text { Private } \\
\text { Banks }\end{array}$ & 0.41 & 0.47 & 0.88 & 4.20 & 2.80 & 7.00 & 5.10 & 3.21 & 8.31 & 5.49 & 3.65 & 9.14 \\
\hline
\end{tabular}

Source: www.pmjdy.gov.in

\section{PMJDY progress from 2014-2017}

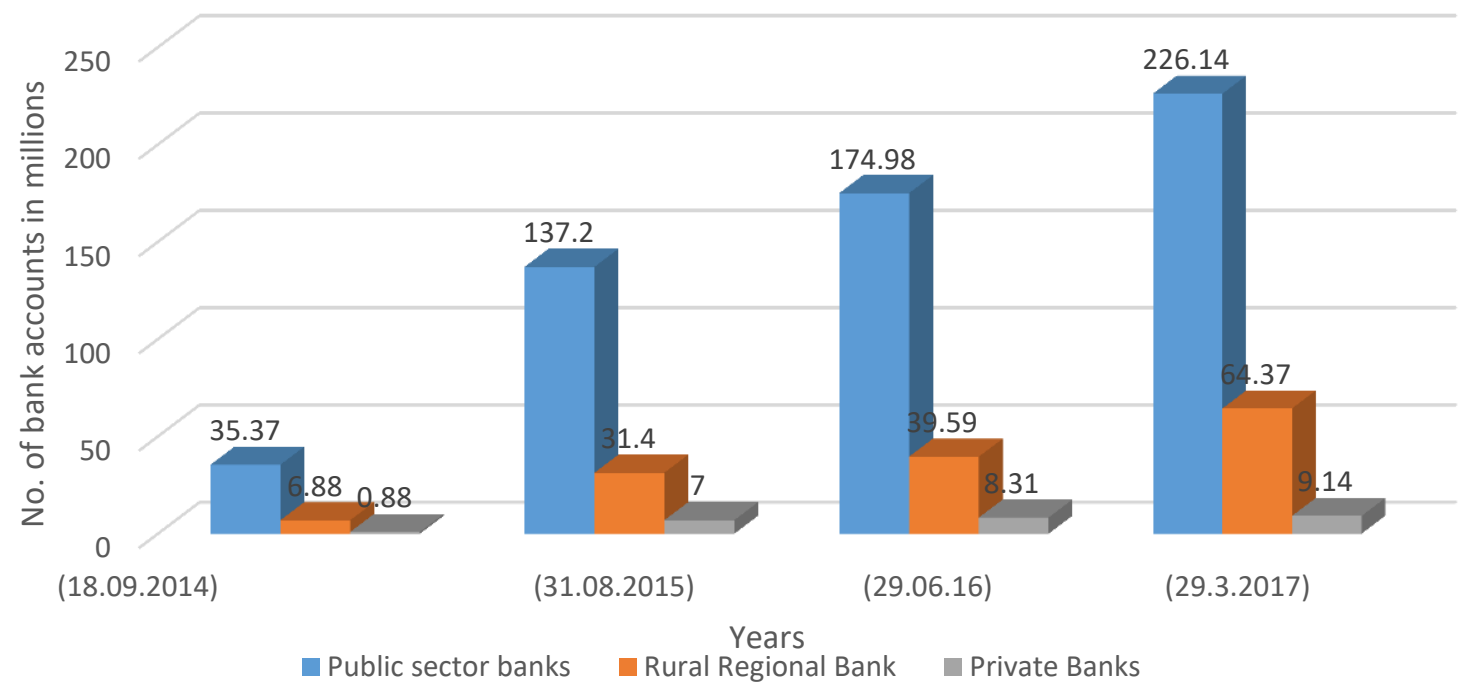

Figure 1:

\section{Research Methodology}

\subsection{Objective of Study}

1) To know implications and effectiveness of PMJDY.

2) To study the current status of PMJDY.

3) To know the awareness of the scheme among the people with their socio economic backgrounds. 
Sampling design: 200 rural households of Jaipur district has been selected (constitutes 1207 individuals which includes 197 women members). Jaipur district is relatively well developed in comparison to other district, if we found persistent financial exclusion in this district where financial inclusion is expected to be high, then financial exclusion is more than likely to be prevalent elsewhere.

Methods of data collection: Both primary and secondary data has been used. A structured questionnaire was developed for the primary data collection. However secondary data sources have also been used to have a deep understanding of the topic. Official websites of department of finance ministry, PMJDY website and other related papers are used.

Research tools: Data collected for the study have been analyzed and presented in tables and graphs. Statistical tools such as Simple percentage, Mean, Standard deviation and correlation have been used.

\subsection{Research Hypothesis}

H01: There is an association between demographic variables and awareness level of PMJDY among rural households.

H02: There is a relationship between sources of financial inclusion and awareness level of PMJDY among rural households.

H03: There is a relationship between awareness about PMJDY and its benefit received form government.

In Table 3 we provide a quick snapshot of the profile of respondents. In the given sample size of 200 households, with 1,790 individuals, there are 171 households have bank accounts. At the household level, 85.5 percent respondents are financially included (i.e. they possess bank account). With regards to education the highest (most) educated member of the household was considered. Majority of individuals in the household were illiterate ( 81.5 percent), whereas number of literate persons were 56.5. Data on annual income is representative of the aggregate household income. The low-income households (annual income, less than 1 lakh) were only $4 \%$ and $47 \%$ respondents reported annual income greater than 3 lakhs. 
Table 3:

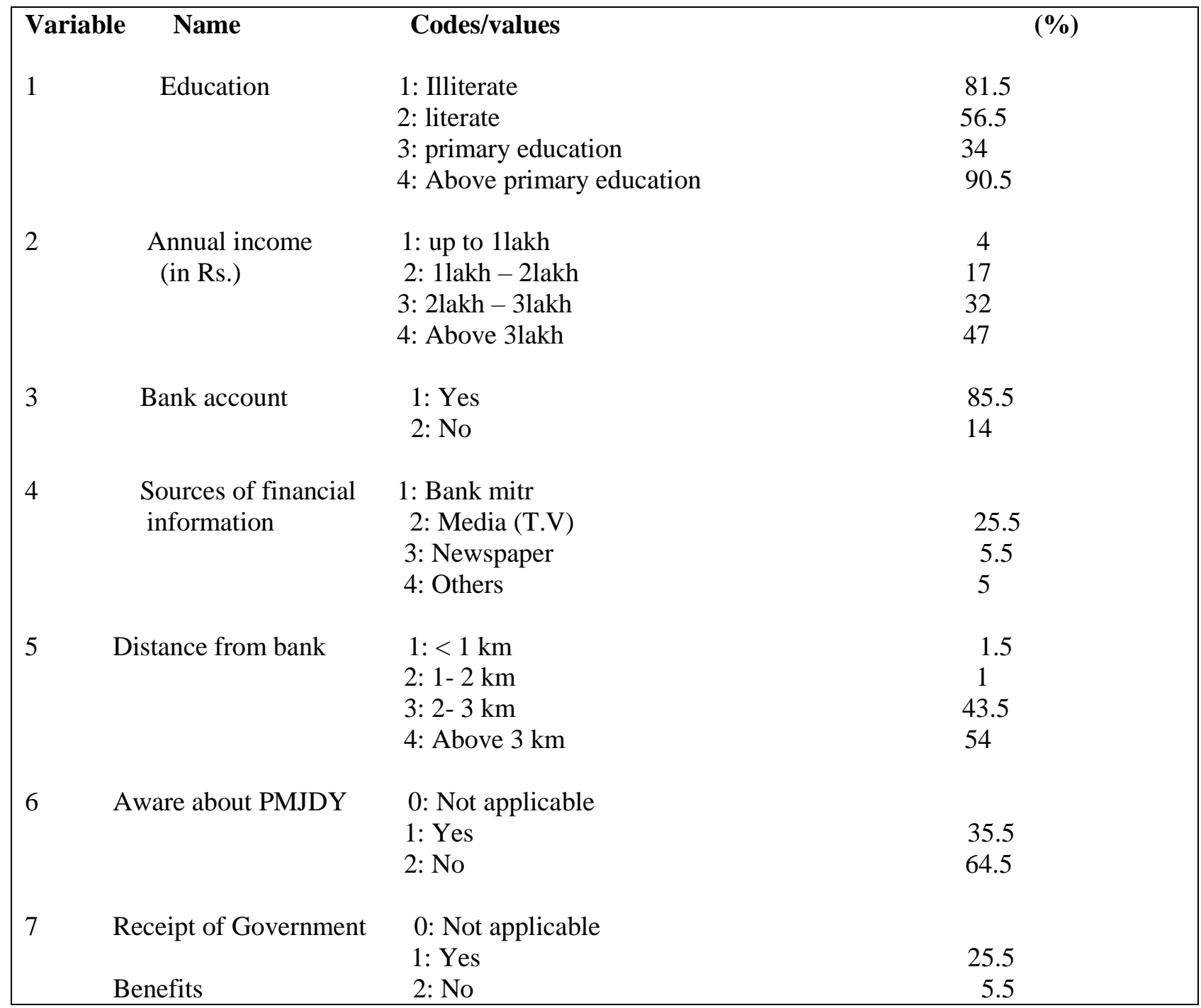

Source: Primary data

Financial information about PMJDY was received Media(T.V.) by majority (25.5 percent), newspaper (5.5 percent). Only one household reported receiving financial information from bank mitr. Banking facilities were available at distances greater than $3 \mathrm{~km}$ for 54 percent of respondents. The households showed that only $35.5 \%$ are aware about PMJDY. Close to 51 percent of respondents were in receipt of government benefits.

H01: There is an association between demographic variables and awareness level of PMJDY among rural households. 
Correlation test for demographic variables and awareness level of PMJDY among rural household in Rajasthan

\begin{tabular}{|l|l|l|l|l|}
\hline Variable & Mean & Std. deviation & Correlation & Sig. (2-tailed) \\
\hline $\begin{array}{l}\text { Distance from nearest bank } \\
\text { and awareness about PMJDY }\end{array}$ & 3.485 & .6723 & .022 & .753 \\
\hline $\begin{array}{l}\text { Annual income and awareness } \\
\text { about PMJDY }\end{array}$ & 3.220 & .8691 & $-.161^{*}$ & .023 \\
\hline $\begin{array}{l}\text { Bank account and awareness } \\
\text { about PMJDY }\end{array}$ & 1.135 & .3569 & $.252^{* *}$ & .000 \\
\hline Awareness about PMJDY & 1.645 & .4797 & - & - \\
\hline
\end{tabular}

*. Correlation is significant at the 0.05 level (2-tailed).

**. Correlation is significant at the 0.01 level (2-tailed).

b. List wise $\mathrm{N}=200$

Measures of central tendency is used to summarize the data of demographic variables and Measure of dispersion was computed to understand the variability of demographic variables for awareness about PMJDY. A Pearson correlation was run to determine the relationship between demographic variables and awareness about PMJDY. There was a weak correlation between distance from bank and awareness about PMJDY $(r=.022, p>.05) \mathrm{p}$ value exceeds alpha, it is not statistically significant. Thus, we fail to reject the null and conclude that there is association between distance from bank and awareness about PMJDY. Annual income shows negative correlation ( $\mathrm{r}=-.161, \mathrm{p}>.05)$ and bank account shows positive correlation $(\mathrm{r}=.252, \mathrm{p}<.05)$. Therefore, it can be concluded that there is a relationship between demographic variables and awareness level of PMJDY.

H02: There is a relationship between sources of financial inclusion and awareness level of

\begin{tabular}{|l|l|l|l|l|}
\hline Variable & Mean & Std. deviation & Correlation & Sig. (2-tailed) \\
\hline $\begin{array}{l}\text { Sources of financial inclusion } \\
\text { and awareness about PMJDY }\end{array}$ & .875 & 1.2479 & $-.931^{* *}$ & .000 \\
\hline Awareness about PMJDY & 1.645 & .4797 & - & - \\
\hline
\end{tabular}

PMJDY among rural households.

**. Correlation is significant at the 0.01 level (2-tailed).

b. List wise $\mathrm{N}=200$

There is negative correlation between sources of financial inclusion and awareness about PMJDY ( $r=-.931, p<.05)$ the relationship between these variables is negative, $\mathrm{p}$ level shows that correlation is statistically significant. Thus, we fail to reject the null and conclude that there is association between sources of financial inclusion and awareness about PMJDY. 
H03: There is a relationship between awareness about PMJDY and its benefit received from government.

\begin{tabular}{|l|l|l|l|l|}
\hline Variable & Mean & Std. deviation & Correlation & Sig. (2-tailed) \\
\hline $\begin{array}{l}\text { Receipt of government benefit } \\
\text { and awareness about PMJDY }\end{array}$ & .367 & .5783 & $-.480^{* *}$ & .000 \\
\hline Awareness about PMJDY & 1.645 & .4797 & - & - \\
\hline
\end{tabular}

**. Correlation is significant at the 0.01 level (2-tailed).

b. List wise $\mathrm{N}=199$

Receipts of govt. benefit and awareness about PMJDY shows ( $\mathrm{r}=-.480, \mathrm{p}<.01)$ than it can be concluded that there is a statistically significant correlation between the two variables. That means, increases or decrease in government receipt do significantly relate to increase or decrease in awareness level of PMJDY.

\subsection{Challenges}

Many cases have been detected that, where an individual has opened more than one account in various banks. Budgetary provisions have not been made by the government to provide incentives, otherwise the financial status of the banks may be ruined. Insurance companies have to fix a nominal premium to cover the risk of the account holders in case it is not done the state owned LIC may batter with financial losses. Overdraft facility needs to be properly regulated, as the same is the discretionary of the concerned banks. Many banks may decline to extend the overdraft facility therefore defeating the purpose. Business correspondents if made to accomplish the objective may misuse the authority and thereby making the life of people under below poverty line miserable.

\section{Conclusion}

The findings of this research are helpful in understanding the influence of variety of factors on the access to banking services of rural households. The findings are as follows:

A natural spin-off of high income and high education profile of respondents is their financially included status. The significant contribution of PMJDY awareness in linking the marginalized with the formal banking institutions is revealed. Respondents are more likely to be financially included at closer distances from Bank. Financial information from various sources (Bank mitr, newspaper, T.V., friends etc.) has helped to increase inclusion. Thus banks and policy makers should work in close co-ordination to spread financial information as those efforts are seen to directly impact their business. Efforts from banks to spread financial information have made no headway, as only one respondent reported to receive financial information from the bank. In this regard we have two suggestions to offer:

1) Banks should persuade policy makers and Government to spread financial information, as those efforts are seen to directly impact their business; and

2) Banks should also take more interest in spreading financial information. Banks are suggested to put efforts to tap low-income households in rural areas, as they are not just potential markets for banks, but catering to them is part of their social responsibility as well. 


\section{References}

[1] Aiyar, Swaminathan S. Anklesaria (2014). "Mr. MODI GETS CONGRESSISED', Economic Times, 3 September.

[2] Barua, A., R. Kathuria, and N. Malik. (2016). "THE STATUS OF FINANCIAL INCLUSION, REGULATION, AND EDUCATION IN INDIA”, ADBI Working Paper 568. Tokyo: Asian Development Bank Institute.

[3] Chopra, Puneet (2014). "DOES THE NEW INCLUSION SCHEME RISK ADDING A RS. 1,000 BILLION SUBSIDY BURDEN?", Microsave blog, August. Available at http://blog.microsave.net/does-the-newinclusion-scheme-risk-adding-a-rs-1000-billionsubsidyburden/

[4] Dr. Vinit Kumar, and Dolly Singh (2015). PMJDY: A CONCEPTUAL ANALYSIS AND INCLUSIVE FINANCING", International Journal of Innovative Social Science and Humanities Research.

[5] Government of India (2014). "PRADHAN MANTRI JAN DHAN YOJANA - A NATIONAL MISSION ON FINANCIAL INCLUSION". Department of Financial Services, Ministry of Finance, New Delhi. Available at http://financialservices.gov.in/banking/PMJDY\%20BROCHURE\%20Eng.pdf

[6] Gwalani H. and Parkhi S. (2014). "FINANCIAL INCLUSION- BUILDING A SUCCESS MODEL IN THE INDIAN CONTEXT", Procedia - Social and Behavioral Sciences 133, 372 378.

[7] M.S. Sriram (2015). "INCLUSIVE FINANCE INDIA REPORT 2015", New Delhi. SAGE publication.

[8] Nair, T. and Tankha, A. (2014). “INCLUSIVE FINANCE INDIA REPORT 2014”, An Access Publication.

[9] Rajan, R. (2014). “ECONOMIC AND FINANCIAL OUTLOOK”, FICCI-IBA Annual Banking Conference, Reserve Bank of India, September 15. Available at http://www.rbi.org.in/scripts/bs_viewspeeches.aspx.

[10] Shetty, S.L. and Bipin K. Deokar (2014). "FINANCIAL INCLUSION DIFFERENCES BETWEEN THE GOVERNMENT AND RBI?", Economic and Political Weekly, Vol. XLIX(35), 12-15.

[11] Singh, Charan and Gopal Naik (2014). "FOR THE UNBANKED", Indian Express, 12 August.

[12] Sahoo S. (2013). "FINANCIAL STRUCTURES AND ECONOMIC DEVELOPMENT IN INDIA: AN EMPIRICAL EVALUATION”, RBI working paper series, Department of economic and policy research.

[13] Tewari, R. (2014). "JAN DHAN YOJANA: CONCERN OVER SCOPE OVER MISUSE, SLOW ROLLOUT OF DEBIT CARDS”, Indian Express, 10 September, 15.

[14] Thangasamy E. (2014). "FINANCIAL INCLUSION IN NORTH EAST INDIA: AN ANALYTICAL STUDY", International Journal of Commerce, Business and Management, 3(1), 180-188.

[15] World Bank (2014), GLOBAL FINANCIAL DEVELOPMENT REPORT 2014”, Washington, D.C.: World Bank. Available at http://econ.worldbank.org/WBSITE/EXTERNAL/EXTDEC/EXTGLOBALFINREPORT/0,conte ntMDK:23491959 pagePK:64168182 piPK:64168060 theSitePK:8816097,00httml

*Corresponding author.

E-mail address: sneha8301@gmail.com 